BENM 2021

International Scientific and Practical Conference "Biotechnology, Ecology, Nature Management"

\title{
DETERMINATION OF THE THRESHOLD CONCENTRATION OF ANOLYTE FOR FRESHWATER FISH SPECIES
}

\author{
Kuchikhin A. Yu. (a)* \\ *Corresponding author \\ (a) K.G. Razumovsky Moscow State University of Technologies and Management (the First Cossack University), \\ Russia, email: kuchikhin@gmail.com
}

\begin{abstract}
To date, various preparations are used in the fishing industry to process both the fish itself and fishbreeding tanks and inventory. Such drugs include formalin, alcohol, manganese, solutions of chlorhexidine and hydrogen peroxide and cyanide-based drugs, including for the treatment of diseases of various etymologies, such as bacterial, viral, parasitic and fungal diseases. These drugs have many disadvantages, with regard to their toxicity and accumulation in the organs and tissues of fish, the complexity of application, toxicity both for the fish themselves and for people in contact with the substance, a high price. Anolyte, which is a broad-spectrum antiseptic, can act as a universal preparation for both the treatment of fish themselves and fish farming equipment. The production technology itself is not new, but this substance has never been widespread in the fishing industry. Anolyte acts with all the necessary requirements for this. For the use of anolyte for the treatment of fish stock, it is necessary to establish the lethal and threshold concentrations of this substance in the water. In this article, experimental methods are used to determine concentrations for freshwater fish, such as: Crucian carp, Alburnus alburnus, Ctenopharyngodon idella, Perca fluviatilis, Danio rerio, Poecilia reticulata, Cyprinus carpio.
\end{abstract}

2672-8575 @ 2022 Published by European Publisher.

Keywords: Alburnus alburnus, Ctenopharyngodon idella, Cyprinus carpio, Perca fluviatilis, Poecilia reticulata 


\section{Introduction}

Anolyte ANK, produced in installations of the STEL-10N-120-01 type of various capacities by electrochemical treatment of a solution of sodium chloride in drinking water, is a colorless transparent liquid with the smell of chlorine, containing highly active oxygen compounds of chlorine, etc. (Shiryakova, 2018)

Depending on the purpose, an anolyte with an active chlorine content of $0.01 \%, 0.02 \%, 0.05 \%$ and a $\mathrm{pH}$ value from 7.2 to 8.4 is obtained and used (Aliev et al., 2016).

Anolyte has antimicrobial (virucidal, bactericidal, tuberculocidal, fungicidal, sporocidal) and washing properties. Schematically, the device is shown in Figure 1 (Order 295).

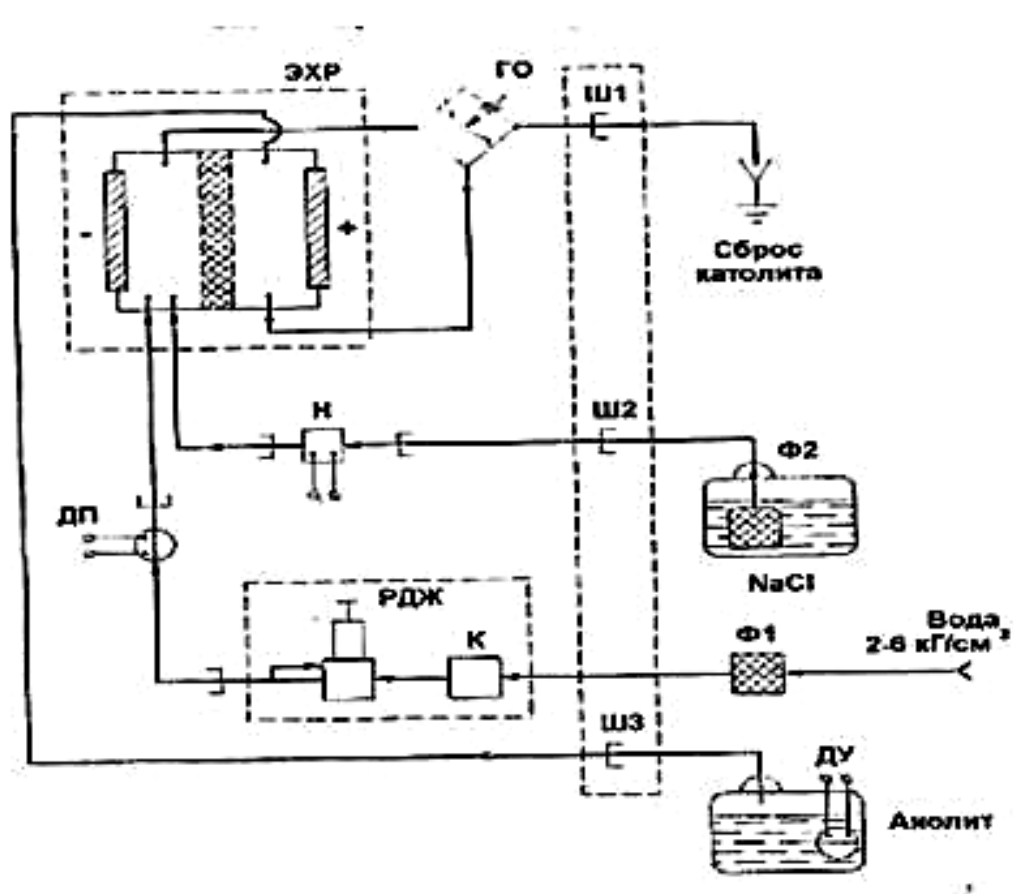

Figure 1. Device diagram

ЭХР - electrochemical reactor, H - saline solution, ДП - flow sensor, РДЖ - liquid pressure regulator, К- electromagnetic valve, ГО - gas separator, Ф1 - pre-cleaning filter, Ф2 - glass filter, ДУ anolyte level sensor (GOST R 58577, 2020)

Anolyte, according to the degree of exposure to the body, belongs to the 4th class of low-hazard substances according to GOST 12.1.007 when administered into the stomach, applied to the skin, is slightly toxic when administered parenterally, does not have a local irritating effect on the skin and mucous membranes of the eyes. An anolyte with an active chlorine content of $0.05 \%$ causes irritation of the upper respiratory tract and mucous membranes of the eyes with free evaporation, at lower concentrations of active chlorine, the anolyte does not have an irritating effect (Butko et al., 2019)

Anolite was previously intended for disinfection of various objects (indoor surfaces, patient care items, dishes, underwear, toys, sanitary equipment, cleaning material) for bacterial infections (including tuberculosis) (Petrova et al., 2020), viral (including hepatitis with parenteral transmission mechanism, 
HIV infection) and fungal (including candidiasis, dermatophytosis) etiology (Popov, 2021), as well as for disinfection, pre-sterilization cleaning and sterilization of medical products made of glass, plastics, rubbers, metals (titanium alloys) in the medical and preventive institutions (Bakhir, 2003).

\section{Problem Statement}

Regulations on the use of toxic substances in aquaculture are currently being tightened. Many decontaminating preparations intended for both inventory processing and fish processing have a number of disadvantages, such as high toxicity, accumulation of fish products in the tissues and subsequently causing allergic and other reactions among consumers, high price. In the current situation, it is necessary to find and use an alternative means for disinfection, disease control, which does not accumulate in the tissues of fish and has a lower cost. Such a substance may be an anolyte.

\section{Purpose of the Study}

For use in aquaculture of any substance with which the fish comes into contact, it is necessary to know the limit, threshold and lethal concentrations for the cultivated species. The purpose of this work is to determine the maximum permissible concentrations of anolyte for various fish species.

\section{Research Methods}

7 species of fish were selected for the experiment. The experiment consisted in placing fish stocks in anolyte solutions of different concentrations and monitoring fish for 96 hours (ORDER No. 695 of August 4, 2009 On approval of Methodological Guidelines for the development of Water quality Standards for Water Bodies of fisheries Significance, including standards for maximum permissible concentrations of harmful substances in the waters of water bodies of fisheries significance) and determining the livestock that successfully exist in a specific concentration of solution.

Since the anolyte is a solution, for the experiment, an anolyte solution containing $500 \mathrm{mg}$ of active chlorine per liter was taken as a 100\% solution (Belko \& Baran, 2018). Then the anolyte was diluted with water passed through a system of osmotic filters in different concentrations. An internal Barbus Filter WP-310 filter with aeration function, with a capacity of up to $200 \mathrm{l} / \mathrm{h}$, was installed in the container with each solution. The lighting during the entire experiment was natural, the water temperature for different species was from 15 to $20^{\circ} \mathrm{C}$ (Korovushkin, 2018). During the entire experiment, the fish were not fed. (Petrova, et al., 2018)

Originally was composed of the following solution concentrations: $100 \%, 75 \%, 50 \%, 40 \%, 30 \%$, $20 \%, 10 \%, 5 \%, 2,5 \%, 1 \%$.

However, for some species, such as Guppies, zebrafish and Bleak, has increased the concentrations of the solutions, due to the high sensitivity to the active substance. During the experiment, it was possible to establish the symptoms of anolyte intoxication (Burak et al., 2008). These symptoms include: peeling of fat all over the body and folding it, filling the body of fish on its side, peeling of the inter-radial skin, burning of the gill petals (Lurye, 2018). 
Fish control was carried out after 6, 12, 24, 48, 96 hours. During the experiment, individuals in solutions with an anolyte content above $2.5 \%$ did not survive in any of the control groups. When assessing the condition of fish as a result, it is formed according to three indicators:

1. A-the behavior of the fish is normal, there are no deviations observed

2. $\mathrm{B}$ - there are deviations in the behavior and condition of the fish

3. C-object is dead

In anolyte solutions with a concentration of $40 \%$ or higher, decomposition processes were suspended, and even on the second day of the body being in water, the gill petals retained their color. The results are presented in the next chapter.

\section{Findings}

As a result of the study, lethal and maximum concentrations of anolyte were established for each species. Anolyte concentrations for Crucian carp are shown in the table 1:

Table 1. Concentrations for Crucian carp

\begin{tabular}{cccccc}
\hline & $\mathbf{6}$ hours & $\mathbf{1 2}$ hours & $\mathbf{2 4}$ hours & $\mathbf{4 8}$ hours & $\mathbf{9 6}$ hours \\
\hline $5 \%$ & $\mathrm{~B}$ & $\mathrm{~B}$ & $\mathrm{C}$ & - & - \\
$2,5 \%$ & $\mathrm{~B}$ & $\mathrm{~B}$ & $\mathrm{~B}$ & $\mathrm{~B}$ & $\mathrm{C}$ \\
$1 \%$ & $\mathrm{~B}$ & $\mathrm{~B}$ & $\mathrm{~A}$ & $\mathrm{~A}$ & $\mathrm{~A}$ \\
$0,5 \%$ & $\mathrm{~A}$ & $\mathrm{~A}$ & $\mathrm{~A}$ & $\mathrm{~A}$ & $\mathrm{~A}$ \\
\hline
\end{tabular}

\section{For Carp:}

$1 \%$ is the threshold concentration, $2.5 \%$ is fatal.

When trying to gradually increase the concentration of the analyte in the solution by $1 \%$ during the day, the crucian sustained a concentration of $2.7 \%$. Concentrations for Alburnus alburnus are shown in the table 2:

Table 2. Concentrations for Alburnus alburnus

\begin{tabular}{cccccc}
\hline & $\mathbf{6}$ hours & $\mathbf{1 2}$ hours & $\mathbf{2 4}$ hours & $\mathbf{4 8}$ hours & $\mathbf{9 6}$ hours \\
\hline $5 \%$ & $\mathrm{C}$ & - & - & - & - \\
$2,5 \%$ & $\mathrm{~B}$ & $\mathrm{C}$ & - & - & - \\
$1 \%$ & $\mathrm{~B}$ & $\mathrm{~B}$ & $\mathrm{C}$ & - & - \\
$0,5 \%$ & $\mathrm{~B}$ & $\mathrm{~B}$ & $\mathrm{~B}$ & $\mathrm{~B}$ & $\mathrm{C}$ \\
$0,25 \%$ & $\mathrm{~B}$ & $\mathrm{~B}$ & $\mathrm{~B}$ & $\mathrm{~B}$ & $\mathrm{~A}$ \\
$0,1 \%$ & $\mathrm{~B}$ & $\mathrm{~A}$ & $\mathrm{~A}$ & $\mathrm{~A}$ & $\mathrm{~A}$ \\
\hline
\end{tabular}

In the case of Bleak in a solution of $0.1 \%$, the sluggish behavior is determined by stress during transplantation, and not by the influence of the active substance. For Bleaching:

$0.25 \%$ - the maximum concentration, $0.5 \%$ - fatal.

When trying to gradually increase the concentration, the maximum volumes did not significantly increase. Concentrations for Ctenopharyngodon idella are shown in the table 3: 
Table 3. Concentrations for Ctenopharyngodon idella

\begin{tabular}{cccccc}
\hline & $\mathbf{6}$ hours & $\mathbf{1 2}$ hours & $\mathbf{2 4}$ hours & $\mathbf{4 8}$ hours & $\mathbf{9 6}$ hours \\
\hline $5 \%$ & $\mathrm{~B}$ & $\mathrm{C}$ & - & - & - \\
$2,5 \%$ & $\mathrm{~B}$ & $\mathrm{C}$ & - & - & - \\
$1 \%$ & $\mathrm{~B}$ & $\mathrm{~B}$ & $\mathrm{~B}$ & $\mathrm{C}$ & - \\
$0,5 \%$ & $\mathrm{~B}$ & $\mathrm{~B}$ & $\mathrm{~B}$ & $\mathrm{~B}$ & $\mathrm{C}$ \\
$0,25 \%$ & $\mathrm{~A}$ & $\mathrm{~A}$ & $\mathrm{~A}$ & $\mathrm{~A}$ & $\mathrm{~A}$ \\
\hline
\end{tabular}

For the White Cupid:

$0.25 \%$ - threshold, $0.5 \%$ - fatal.

When trying to gradually increase the concentrations, the fish adapted to a concentration of $0.5 \%$ on the second day. Concentration for Perca fluviatilis are shown in the table 4

Table 4. Concentrations for Perca fluviatilis

\begin{tabular}{cccccc}
\hline & 6 hours & 12 hours & 24 hours & $\mathbf{4 8}$ hours & 96 hours \\
\hline $5 \%$ & $\mathrm{~B}$ & $\mathrm{~B}$ & $\mathrm{C}$ & - & - \\
$2,5 \%$ & $\mathrm{~B}$ & $\mathrm{~B}$ & $\mathrm{~B}$ & $\mathrm{~B}$ & $\mathrm{C}$ \\
$1 \%$ & $\mathrm{~B}$ & $\mathrm{~B}$ & $\mathrm{~B}$ & $\mathrm{~A}$ & $\mathrm{~A}$ \\
$0,5 \%$ & $\mathrm{~A}$ & $\mathrm{~A}$ & $\mathrm{~A}$ & $\mathrm{~A}$ & $\mathrm{~A}$ \\
\hline
\end{tabular}

For Perch:

$2.5 \%$ - fatal, $1 \%$ - threshold.

A gradual increase in the concentration for this species was not carried out. Concentrations for Danio rerio are shown in the table 5:

Table 5. Concentrations for Danio rerio

\begin{tabular}{cccccc}
\hline & $\mathbf{6}$ hours & $\mathbf{1 2}$ hours & $\mathbf{2 4}$ hours & $\mathbf{4 8}$ hours & $\mathbf{9 6}$ hours \\
\hline $5 \%$ & $\mathrm{C}$ & - & - & - & - \\
$2,5 \%$ & $\mathrm{C}$ & - & - & - & - \\
$1 \%$ & $\mathrm{~B}$ & $\mathrm{~B}$ & $\mathrm{C}$ & - & - \\
$0,5 \%$ & $\mathrm{~B}$ & $\mathrm{~B}$ & $\mathrm{C}$ & - & - \\
$0,25 \%$ & $\mathrm{~B}$ & $\mathrm{~B}$ & $\mathrm{~B}$ & $\mathrm{~B}$ & $\mathrm{C}$ \\
$0,1 \%$ & $\mathrm{~B}$ & $\mathrm{~B}$ & $\mathrm{~B}$ & $\mathrm{~B}$ & $\mathrm{~A}$ \\
$0,05 \%$ & $\mathrm{~B}$ & $\mathrm{~A}$ & $\mathrm{~A}$ & $\mathrm{~A}$ & $\mathrm{~A}$ \\
\hline
\end{tabular}

For Danio:

$0.1 \%$ - threshold, $0.25 \%$ - fatal.

A gradual increase in concentrations for this species was not carried out. The extremely low concentrations of the analyte in the solution are caused by the very high sensitivity of this object. Concentrations for Poecilia reticulate are shown in the table 6: 
Table 6. Concentrations for Poecilia reticulate

\begin{tabular}{cccccc}
\hline & $\mathbf{6}$ hours & $\mathbf{1 2}$ hours & $\mathbf{2 4}$ hours & $\mathbf{4 8}$ hours & $\mathbf{9 6}$ hours \\
\hline $5 \%$ & $\mathrm{C}$ & - & - & - & - \\
$2,5 \%$ & $\mathrm{~B}$ & $\mathrm{C}$ & - & - & - \\
$1 \%$ & $\mathrm{~B}$ & $\mathrm{~B}$ & $\mathrm{~B}$ & $\mathrm{C}$ & - \\
$0,5 \%$ & $\mathrm{~B}$ & $\mathrm{~B}$ & $\mathrm{~B}$ & $\mathrm{~B}$ & $\mathrm{~B}$ \\
$0,25 \%$ & $\mathrm{~B}$ & $\mathrm{~B}$ & $\mathrm{~A}$ & $\mathrm{~A}$ & $\mathrm{~A}$ \\
$0,1 \%$ & $\mathrm{~A}$ & $\mathrm{~A}$ & $\mathrm{~A}$ & $\mathrm{~A}$ & $\mathrm{~A}$ \\
\hline
\end{tabular}

For Guppies:

$0.25 \%$ - threshold, $1 \%$ - threshold.

At a concentration of $0.5 \%$, the Guppy falls into a state of suspended animation and comes out of it only when moving to cleaner water, in such a state it does not react to food, but does not die. A gradual increase in concentrations was not carried out. Concentrations for Cyprinus carpio are shown in the table 7:

Table 7. Concentrations for Cyprinus carpio

\begin{tabular}{cccccc}
\hline & $\mathbf{6}$ hours & $\mathbf{1 2}$ hours & $\mathbf{2 4}$ hours & $\mathbf{4 8}$ hours & $\mathbf{9 6}$ hours \\
\hline $5 \%$ & $\mathrm{~B}$ & $\mathrm{C}$ & - & - & - \\
$2,5 \%$ & $\mathrm{~B}$ & $\mathrm{~B}$ & $\mathrm{~B}$ & $\mathrm{~B}$ & $\mathrm{C}$ \\
$1 \%$ & $\mathrm{~B}$ & $\mathrm{~B}$ & $\mathrm{~B}$ & $\mathrm{~B}$ & $\mathrm{~A}$ \\
$0,5 \%$ & $\mathrm{~B}$ & $\mathrm{~A}$ & $\mathrm{~A}$ & $\mathrm{~A}$ & $\mathrm{~A}$ \\
\hline
\end{tabular}

For Carp:

$1 \%$ - threshold, $2.5 \%$ - fatal.

With a gradual increase in concentrations, it was possible to bring the fish to a normal existence in a solution of $2.5 \%$. The data on Carp do not significantly differ from the data for the White Amur, this indicates a similar resistance to the substance.

\section{Conclusion}

The concentration of anolyte for disinfection is diluted 1 to 1000 , on average, fish species withstand and normally exist in solutions of 1 to 200. Aquarium fish and test objects withstand much lower concentrations (Prokopenko et al., 2019). Anolyte is required much less than its analogues, it is cheaper and the fish is able to exist normally in its solutions. Damage to the gill lobes at high concentrations of anolyte is the main cause of fish death, since the burning of the petals cannot be restored (Kovalenko, 2018). However, the concentration of anolyte in the solution decreases with time, this is due to the properties of the activity of chlorine ions, as a result, the following conclusions can be drawn: 
1. The maximum permissible concentrations may vary both from the water from which the anolyte is made, and from the liquid added to the anolyte, therefore, an impact assessment should be carried out on each local liquid separately.

2. It is recommended to use the lowest concentration and gradually increase it to the required values.

3. Since the anolyte changes the $\mathrm{pH}$ of the medium and worsens the solubility of oxygen, it should be used with caution on fish that are demanding a high oxygen content and a stable $\mathrm{pH}$.

\section{References}

Aliev, A. A. Shapiev, B. I., \& Trunova, S. A. (2016). The effectiveness of the use of electrochemically activated sodium chloride solution with insecticidal agents. Problems of medical ecology. VI Republican Scientific and Practical Conference, 226-230.

Bakhir, V. M. (2003). Efficiency and safety of chemical means for disinfection of pre-sterilization cleaning and sterilization. Disinfection case, 1, 29-36.

Belko, A. A., \& Baran, V. P. (2018). Physico-chemical parameters of anolyte and catholyte under various storage conditions, Scientific notes of the educational institution. Vitebsk Order of the Badge of Honor State Academy of Veterinary Medicine, 54(1), 20-24.

Burak, I. I. (2008). Hygiene: Textbook. Manual. I. I. Burak. I. I. Burak, \& N. I. Miklis (Eds.), VSMU.

Butko, M. P., Popov, P. A., \& Onishchenko, D. A. (2019). Results of determining the corrosion activity of the disinfectant "anolit ANK-super". Bulletin of the Bashkir State Agrarian University, 2(50), 57-60. https://doi.org/10.31563/1684-7628-2019-50-2-57-61

Federal agency for fisheries/ Order No. 695. (2009). On approval of Methodological Guidelines for the development of water quality standards for water bodies of fisheries significance, including standards for the maximum permissible concentrations of harmful substances in the waters of water bodies of fisheries significance on December 22, 2017.

GOST R 58577-2019. (2020). National standard of the russian federation. rules for establishing standards for permissible emissions of pollutants by projected and operating economic entities and methods for determining these standards. https://docs.cntd.ru/document/1200168569

Korovushkin, A. A. (2018). Improving the technology of rearing carp larvae. Bulletin of the Russian State Agrarian University, 24-30.

Kovalenko, M. V. (2018). Feeding koi carp in industrial conditions. The state and ways of development of aquaculture in the light of import substitution. Amirite.

Lurye, Yu. Yu. (2018). Analytical chemistry of industrial wastewater. Chemistry.

Petrova, O. G., Barashkin, M. I., Milshtein, I. M., \& Patrushev, S. V. (2018). Experimental substantiation of the effectiveness of the import-substituting disinfectant anolit $(\mathrm{ANK}+)$ in veterinary medicine. $\begin{array}{llllll}\text { Agrarian Bulletin of } & \text { the } & 179 .\end{array}$ https://doi.org/10.32417/article_5c3eefbb046991.68794052

Petrova, O. G., Barashkin, M. I., Milshtein, I. M., Kudryashova, E. R., \& Kolobkova, N. I. (2020). Microbiological testing of the disinfectant "neutral anolyte". Bulletin of Biotechnology, 1(22), 20.

Popov, P. A. (2021). Study of acute toxicity and cumulative properties of the "anolit ahk-super" disinfectant on laboratory animals. Bulletin of the Bashkir State Agrarian University, 2(58), 51-54. https://doi.org/10.31563/1684-7628-2021-58-2-51-54

Prokopenko, A. A., Vanner, N. E., \& Filipenkova, G. V. (2019). Studying the bactericidal and disinfecting activity of a new environmentally safe drug anolit ank super. Russian Journal of Problems of Veterinary Sanitation, Hygiene and Ecology, 3(31), 287-293. https://doi.org/10.36871/vet.san.hyg.ecol.201903008

Shiryakova, T. A. (2018). Efficiency of using sodium hypochlorite and neutral anolyte in wastewater disinfection at epidemiologically significant facilities. Vitebsk State Medical University. 